\title{
Effect of COVID-19 Virus on the Patients of Neurological Diseases: Risk and Mechanism
}

\author{
Rishabha Malviya ${ }^{1}$ and Akanksha Sharma ${ }^{1}$ \\ ${ }^{1}$ Galgotia University
}

May 22, 2020

\begin{abstract}
The manuscript aims to describe the effect of COVID-19 virus on the patients suffering with neurological diseases. The outbreak of COVID-19 is serious and it becomes epidemic worldwide. It is observed from the literature survey that COVID19 virus can easily affect the persons having neurological diseases. The manuscript also focuses on the mechanism of action of the COVID-19 virus on the nervous system with precaution majors. Patients with COVID-19 show various symptoms of neurological manifestations including stroke, impaired consciousness, seizures, agitation, unsteadiness, dizziness, confusion, localized neuralgia and cognitive impairment. The COVID-19 virus affect the Central Nervous System, makes the patients clinical condition worse and it may cause the death of the patient. It can be concluded from the literatures that COVID-19 virus versen the neurological condition of patients and may leads to severe manifestations.
\end{abstract}

\section{Hosted file}

Manuscript.doc available at https://authorea.com/users/325177/articles/453174-effect-ofcovid-19-virus-on-the-patients-of-neurological-diseases-risk-and-mechanism 